\title{
Penggunaan Cyclone Ventilator sebagai Kincir Angin penggerak Generator
}

\author{
Bachtera Indarto, ${ }^{*}$ Achaddiad, Susilo Indrawati, Didiek B. Rahmat, dan Hasto Sunarno \\ Jurusan Fisika, Fakultas Matematika dan Ilmu Pengetahuan Alam, \\ Institut Teknologi Sepuluh Nopember (ITS), Kampus ITS Sukolilo, Surabaya 60111
}

\section{Intisari}

Telah dilakukan penelitian dengan menggunakan generator ceiling fan $12 \mathrm{~W}$, dengan jumlah gear 35 dan 60 serta cyclone ventilator dengan jumlah gear 95. Pada kecepatan angin yang sama kecepatan poros generator pada pasangan gear 95/35 lebih besar dibandingkan dengan pasangan gear 95/60. Tegangan keluaran generator untuk pasangan gear 95/35 lebih besar dibandingkan pasangan gear 95/60. Pada pasangan gear 95/35 daya listrik yang dihasilkan generator sebesar 2,0 $\mathrm{mW}$ pada kecepatan angin 4,0 m/s dan kecepatan poros 40,2 rpm.

\begin{abstract}
The research has been conducted using the generator ceiling fan $12 \mathrm{~W}$, the number of gear are 35 and 60 as well as the number of gear cyclone ventilator is 95 . At the same wind speed at the generator shaft speed gear pair $95 / 35$ is greater than that $95 / 60$. The output voltage generator for gear pair $95 / 35$ is larger than gear pair $95 / 60$. In the gear pair $95 / 35$ generator power output of $2.0 \mathrm{~mW}$ at a wind speed is $4.0 \mathrm{~m} / \mathrm{s}$ and spindle speed is 40.2 rpm .
\end{abstract}

KATA KUNCI: cyclone ventilator, daya listrik, kecepatan poros, generator

\section{PENDAHULUAN}

Akhir-akhir ini perhatian pada fenomena penggunaan energi terbarukan khususnya energi angin meningkat dengan cepat. Hal ini disebabkan semakin langkanya keberadaan sumber daya energi tak terbarukan seperti minyak, gas bumi, batu bara. Oleh karena itu perlu adanya reformasi penggunaan energi di berbagai bidang kegiatan yang akan mendorong penggunaan teknologi baru [1]. Salah satu alternatif dari energi terbarukan adalah energi angin. Energi ini mudah diperoleh dan mudah proses produksinya. Energi angin telah banyak digunakan di berbagai bidang seperti pembangkit listrik, tenaga gerak pompa air [2].

Suatu teknologi turbin angin untuk pembangkit tenaga listrik yang sudah dikenal yaitu HAWT (Horizontal Axis Wind Turbin) dan VAWT (Vertical Axis Wind Turbin) [3]. Kelebihan dari turbin angin sumbu vertikal dibandingkan dengan yang sumbu horizontal adalah memiliki sumbu rotasi bertepatan dengan arah angin serta kesederhanaan rancangan sudu-sudu VAWT terutama memiliki bagian simetris dengan chord kon$\operatorname{stan}[4]$.

Cyclone vertilator dapat bertindak sebagai kincir angin penggerak generator cyclone vertilator yang digerakkan oleh angin terdiri dari bagian alas dan bagian atas dalam bentuk rotor yang bertindak seperti turbin, mengkonversi kerja mekanik dari angin untuk menghasilkan gerak rotasi yang dapat memutar komponen generator sehingga timbul tegangan listrik [5].

\footnotetext{
*E-MAIL: bachtera@physics.its.ac.id
}

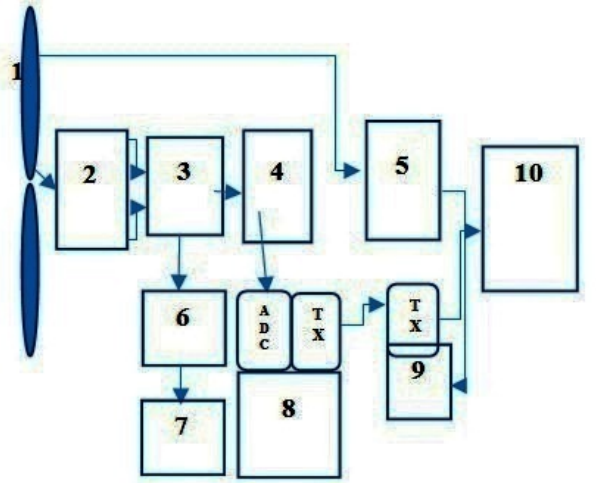
1. Turbin cyclone
2. Generator ceiling fan
3. Rangkaian penyearah 4. Pembagi tegangan
5. Rotary encoder 6. Sumber arus
7. Multimeter 8. Atmega 16
9. Arduino 10. PC/display data

Gambar 1: Diagram blok sistem.

\section{METODOLOGI}

\section{Perancangan sistem}

Peralatan yang digunakan pada penelitian ini antara lain: cyclone ventilator, generator ceiling fan $12 \mathrm{~W}$, gear banding, anemometer propeller, rotary encoder, arduino uno, digital multimeter, blower fan, mikrokontroler atmega 16 dan neraca pegas yang disusun/dirangkai seperti pada Gambar 1 .

Terlihat pada Gambar 1, cyclone ventilator yang berlaku 


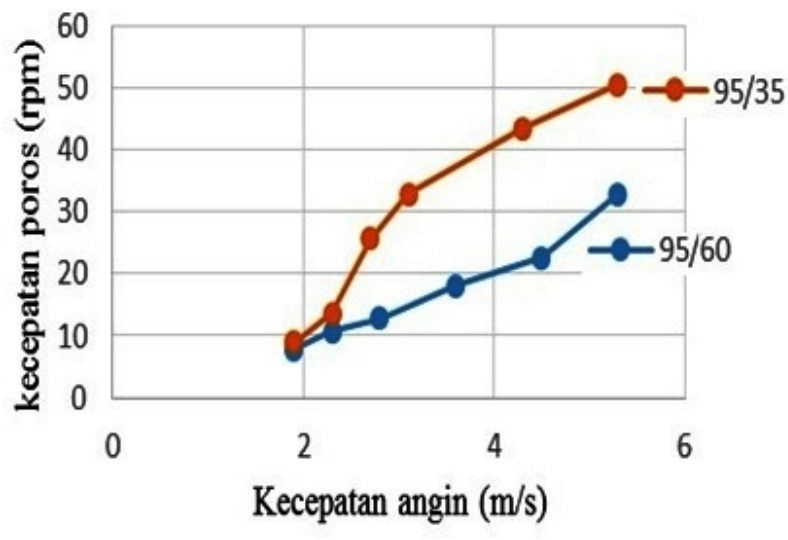

Gambar 2: Grafik pengaruh kecepatan angin terhadap kecepatan poros generator ceiling fan.

sebagai turbin penggerak dikopel dengan ceiling fan dengan menggunakan gear banding. Rotary encoder yang dipasang di bagian atas cyclone ventilator dipakai untuk mengukur kecepatan putar cyclone. Penggunaan arduino adalah sebagai media komunikasi serial antara Atmega 16 dengan PC/Laptop serta mengolah data dari rotary encoder. Sebagai penghasil angin digunakan fan blower dikarenakan angin alami dengan kecepatan yang cukup besar tidak sering terjadi. Tegangan keluaran dari generator diukur dengan multimeter digital. Variasi gear banding yang digunakan gear 95 (untuk poros cyclone) dan 2 gear di ceiling fan yaitu gear 35 dan 60.

\section{Ragam Pengukuran}

Pada penelitian ini dilakukan beberapa pengukuran meliputi

1. Pengukuran pengaruh kecepatan angin terhadap kecepatan poros generator ceiling fan,

2. pengukuran pengaruh kecepatan angin terhadap tegangan generator ceiling fan dengan dan tanpa rangkaian penyearah,

3. pengukuran pengaruh kecepatan angin terhadap daya listrik generator dengan rangkaian penyearah.

\section{HASIL DAN PEMBAHASAN}

\section{Pengaruh kecepatan angin pada kecepatan poros generator}

Grafik pada Gambar 2, menunjukkan hubungan antara kecepatan angin yang mengenai permukaan cyclone ventilator dengan kecepatan poros generator. Semakin besar kecepatan angin yang mengenai cyclone semakin besar kecepatan poros

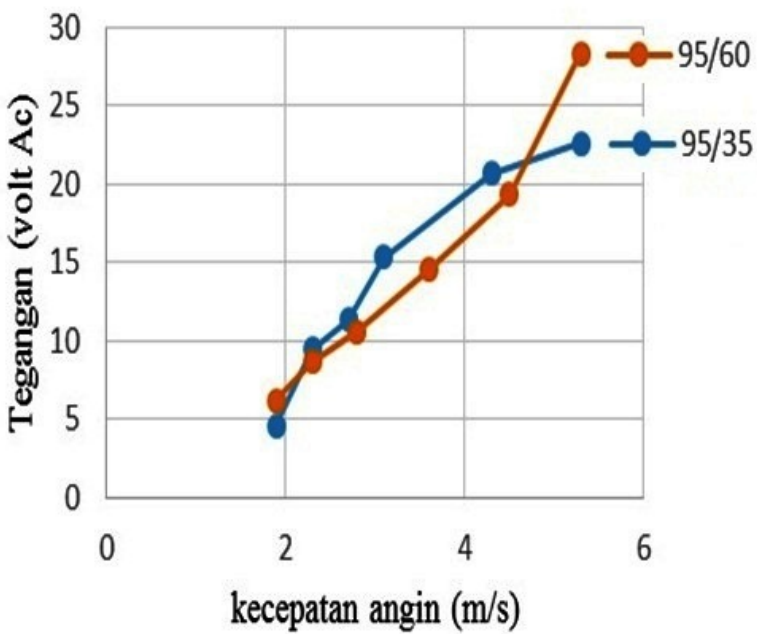

Gambar 3: Grafik pengaruh kecepatan angin terhadap tegangan tanpa penyearah.

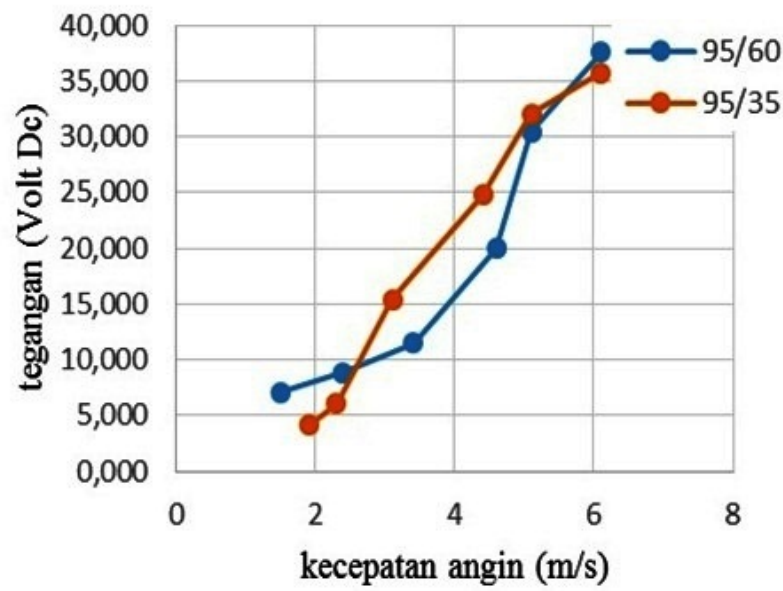

Gambar 4: Grafik pengaruh kecepatan angin terhadap tegangan generator dengan penyearah.

generator ceiling fan. Kecepatan poros generator untuk pasangan gear 95/35 lebih besar dibandingkan dengan pasangan gear 95/60. Hal ini bersesuaian dengan hubungan yang mengatakan bahwa untuk radius yang kecil akan menghasilkan kecepatan poros yang lebih besar. Pada penelitian ini digunakan kecepatan angin sebesar 1,9-5,3 m/s . Pada kecepatan angin $4 \mathrm{~m} / \mathrm{s}$ diperoleh kecepatan poros generator sebesar 40,2 rpm untuk gear 35 dan 20 rpm untuk gear 60 .

\section{Pengaruh kecepatan angin pada tegangan generator}

Hasil pengukuran yang tergambar pada Gambar 3 dan Gambar 4 merupakan pengukuran tegangan pada generator ceiling fan $12 \mathrm{~W}$ tanpa dan dengan rangkaian penyearah. Semakin besar angin yang digunakan untuk memutar cyclone ventilator semakin besar tegangan keluaran generator. Pada Gambar 3 terlihat bahwa tegangan keluaran generator tanpa 


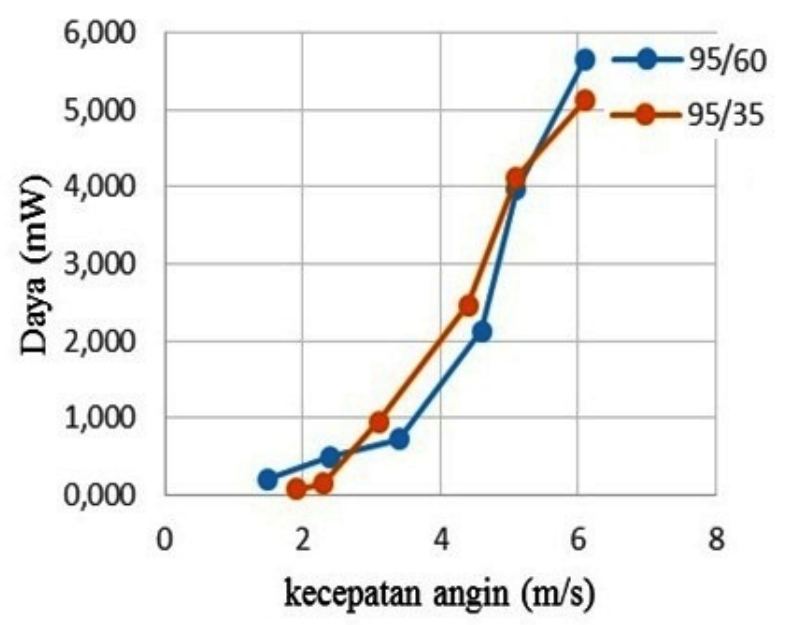

Gambar 5: Grafik penyearah kecepatan angin terhadap daya listrik dengan rangkaian penyearah.

rangkaian penyearah untuk pasangan gear 95/35 relatif lebih besar dibandingkan pasangan gear 95/60 kecuali pada kecepatan angin diatas 4,7 m/s. Sedangkan pada Gambar 4 terlihat bahwa tegangan keluaran generator dengan rangkaian penyearah untuk pasangan gear 95/35 relatif lebih besar dibandingkan dengan pasangan gear 95/60 kecuali pada kecepatan angin dibawah $2,6 \mathrm{~m} / \mathrm{s}$. Semestinya menurut teori berapapun besar kecepatan angin tegangan keluaran generator untuk pasangan gear 95/35 lebih besar dibandingkan dengan pasangan gear 95/60 karena kecepatan poros generator untuk gear 35 lebih besar dibandingkan dengan gear 60. Pada kecepatan angin $4 \mathrm{~m} / \mathrm{s}$ tegangan generator dengan rangkaian penyearah sebesar 21,4 V untuk gear 35 dan $16 \mathrm{~V}$ untuk gear 60.

\section{Pengaruh kecepatan angin pada daya listrik generator dengan rangkaian penyearah}

Gambar 5 menunjukkan grafik perubahan daya listrik keluaran generator terhadap besar kecepatan angin yang menggerakkan cyclone ventilator. Daya listrik pada generator dengan pasangan gear 95/35 menunjukkan nilai lebih besar dibandingkan dengan daya listrik pada generator dengan pasangan gear 95/60. Tetapi, pada kecepatan angin $3,7 \mathrm{~m} / \mathrm{s}$ dan 5,2 $\mathrm{m} / \mathrm{s}$ daya listrik generator untuk kedua pasangan gear menunjukkan nilai yang sama. Pada kecepatan angin 3,7 m/s diperoleh daya listrik sebesar $0,5 \mathrm{~mW}$ dan pada kecepatan $5,2 \mathrm{~m} / \mathrm{s}$ nilai daya listriknya sebesar $4,1 \mathrm{~mW}$. Pada kecepatan angin 4 $\mathrm{m} / \mathrm{s}$ besar daya listriknya $2,0 \mathrm{~mW}$ untuk gear 35 dan $1,5 \mathrm{~mW}$ untuk gear 60 .

\section{SIMPULAN}

Berdasarkan pada hasil pengukuran, diperoleh simpulan sebagai berikut:

1. Kecepatan poros generator ceiling fan untuk pasangan gear 95/35 lebih besar dibandingkan terhadap generator ceiling fan pasangan gear 95/60,

2. tegangan listrik dan daya listrik keluaran generator untuk pasangan gear 95/35 lebih besar dibandingkan generator dengan pasangan gear $95 / 60$,

3. pada kecepatan angin $4 \mathrm{~m} / \mathrm{s}$ diperoleh kecepatan poros generator 40,2 rpm, tegangan listrik keluaran 21,9 Volt dan daya listrik $2,0 \mathrm{mV}$ untuk generator dengan tegangan gear 95/35.
[1] R.D. Maldonado, et al., Energy Procedia, 57, 691-697 (2014).

[2] Q. Huang, et al., Renew. Energy, 76, 401-407 (2015).

[3] W. Tjiu, et al., Renew. Energy, 75, 50-67 (2015).

[4] V. Samsonov, P. Baklushin, J. Wind. Eng. Ind. Aerodyn., 39,
427-433 (1992).

[5] S.-TJ. Lien, N.A. Ahmed, Build. Environ., 45, 108-115 (2010). 